\title{
Familiestriden i I872-73 om N. F. S. Grundtvigs efterladte papirer
}

\author{
Ved Steen Fohansen.
}

I det følgende skal offentliggøres en af Svend Grundtvig i i 872 nedskreven, men hidtil utrykt beretning om den spænding og strid, som kort efter N. F. S. Grundtvigs død den 2. september 1872 opstod mellem hans arvinger. Striden drejede sig om ejendomsretten til eller rådigheden over Gr.s efterladte manuskripter, nøjere bestemt: adgangen til at udnytte disse manuskripter litterært (og pekuniært), og stridens to hovedpersoner var Gr.s enke, komtesse Asta Grundtvig (f. I 826) og Gr.s næstældste søn, professor Svend Grundtvig (f. I824). Spændingen voksede i løbet af september-oktober 1872 til en sådan højde, at det, med Frederik Lange Gr.s ord adskillige år senere, nær var kommet til en proces mellem parterne, hvad dog lykkeligvis i sidste øjeblik blev undgået ${ }^{1}$ ). Et forlig kom istand, en ordning blev fundet, men en ordning, som kom til at sætte sit præg på største delen af Gr.-udgaverne og Gr.-forskningen i tiden fra 1873 til Sv. Gr.s død i i 883. Derfor har denne arvestrid en interesse ud over det rent familiære; den kan opfattes som »supplerende oplysninger dels til visse i Grundtvig-registranten bd. 26 og 27 registrerede papirer nemlig fasc. 535 og Ny kgl. Samling $3698,4^{\circ}$, dels til de sider $\mathrm{i}$ tredie bind af min Gr.-bibliografi, der indeholder en oversigt over de i førnævnte tidsrum udgivne værker af Gr.

Svend Grundtvigs beretning findes i læg 4 af $\mathrm{Ny}$ kgl. Samling $3698,4^{\circ}$ : $\gg \mathrm{Pa}$ pirer vedrørende udgaverne af N.F.S. Grundtvigs Sangværk og Poetiske Skrif- ter«. Sv. Gr.s beretning gengives nøjagtigt efter hans tekst; enkelte tilføjelser er af udgiveren anført i skarp parentes. I selve beretningen gengiver Sv. Gr. (i sin ortografi) flere breve. Forsåvidt originalerne til disse er bevaret $\mathrm{i}$ det kgl. Bibl. (og det er tilfældet med de to første), gengives de efter disse originaler, og Sv. Gr.s eventuelle tilføjelser til dem vil være at finde i noterne.

I. Utrykt brev (i Ny kgl. Saml. $3698,4^{\circ}$ ) fra Fr. L. Gr. i Clinton 2/7 I 884 til Jørgen Bloch. Det hedder her: »Efter min Faders Død var det, som De ved, ikke langt fra at komme til Proces med min Stifmoder, i Anledning af hendes Krav paa udelukkende Besiddelse af og Raadighed over alle min Faders Papirer (osv.) «. 
Svend Gr. nedskrev sin beretning formodentlig i begyndelsen af nov. I 872, hvorved den ikke kom til at dække hele stridens forløb. Derfor suppleres den her med flere breve. Iøvrigt meddeler Svend Gr. selv i sin beretning ordlyden af nogle breve. For så vidt disse også haves i original (i Det kgl. Bibliotek), hvilket er tilfældet med to af dem, gengives de her efter disse originaler, og altså ikke efter Svend Gr.s afskrift.

De to hovedpersoner stod naturligvis ikke alene. Fru Asta havde sine venner (især blandt politikere), og Svend Gr. udgjorde sammen med sine helsøskende modpartiet: arkivar Johan Gr. og fru Meta Boisen samt halvbroderen Frederik Lange Gr., dengang atten år gammel. Pastor C. J. Brandt indtog en mere neutral stilling. Andre deltagere, se noterne i det følgende.

Inden vi giver ordet til beretningen, skal vi erindre om, at den er skrevet af den ene af de to parter selv, Svend Gr., og at den følgelig ikke kan være upartisk. Vi kommer til at se hændelserne i lys af Svend Gr.s opfattelse, og det er måske ikke det heldigste synspunkt. I det hele taget er Svend Gr. hovedpersonen i det følgende, og hele affæren kaster efter min mening først og fremmest et ejendommeligt lys over hans fremfærd og væsen. Fru Asta har blandt Gr.-forskere vistnok været mindre agtet end godt er; det må være på tide, at en retfærdigere vurdering kommer til orde. Hun var levende af sind, kvindelig og vennesæl, når hun mødte forståelse, - demokratisk, liberal, folkelig, sådan som man dengang kunde være det, når man tilhørte adelen. Overfor hende Svend Gr., en meget sammensat karakter, energisk filolog og litterat, officer og ordensmenneske, selvfølende og rethaverisk. Så længe N. F. S. Grundtvig levede, må forholdet mellem hende og stedsønnen have været til at udholde, men efter hans død gik det ikke længere. I sin beretning lader Svend Gr. fru Asta alene være årsagen til, at det brast mellem dem, men vi har jo kun Svend Gr.s ord herfor! Det er ikke sikkert, at de fortæller os hele sandheden, selv om Svend Gr. har troet det. Nu kan læserne selv dømme.

Beretningen, som er uden titel, lyder som følger:

En dag, jeg kan ikke nøjere bestemme når, end at det var mellem I3de og I8de september [1872], da jeg traf fru Grundtvig ene på Tuborg²), udbad jeg mig en samtale med hende angående faders litterære efterladenskab. Jeg

2. Tuborg ग: fru Gr.s villa Store Tuborg, Strandvej, nuværende nr. I 23. 
sagde, at jeg nu for hende $\mathrm{i}$ al venskabelighed og oprigtighed vilde fremsætte den betragtning af forholdet, som vi voksne børn vare enige om. Hvem der var faders litterære arvinger, hans hustru eller hans børn var vistnok et tvivlsomt juridisk spørgsmål; men for så vidt som vi vel vare enige om, at den ret, vi vilde lade gælde var den virkelige ret, som fremgik af en samvittighedsfuld prøvelse af de særlige forhold, så vilde vi jo kunne betragte sagen uden særlig juridisk indsigt.

Ved den ægtepagt, som fader og hun oprettede imellem sig forbeholdt hun sig sin særlige formue, 44000 daler, som under ingen omstændigheder kunde inddrages i Grundtvigs bo, medens han forbeholdt sit bibliotek for sine børn. Indboet skulde være fællesejendom. Men i øvrigt skulde den ene ikke tage arv efter den anden. Dette havde jeg fået ud ved et flygtigt syn på ægtepagten, som hun viste mig dagen efter faders død.

$\mathrm{Nu}$ er der angående litterær ejendomsret en lov, der siger, at den efterladte ægtefælle arver denne forud for børnene. Men denne lov omtaler ikke sådanne tilfælde, hvor ægtefællerne have hver forbeholdt sig deres særskilte formue og udelukket hinanden fra almindelig arv.

Det forekom nu os, at hun ikke med god samvittighed kunde gøre påstand på den arv efter sin mand, som utvivlsomt i pengeværdi langt overgik alt, hvad han i øvrigt havde efterladt sig. Loven havde udelukkende pengeværdier for øje, og ikke noget pietets- eller æres-hensyn. Ejendomsretten over skrifterne førte pengearven med sig, og de to ting kunde ikke adskilles. Når hun altså ikke fandt, at hun kunde gøre fordring på den væsentligste pengearv efter sin mand, samtidig med at hun forbeholdt sig sin egen medbragte formue urørt, så måtte hun også give afkald på at gøre påstand på højhedsretten over det litterære efterladenskab. Hun kunde ikke mene, at dette ikke kom i gode hænder, når jeg og mine søskende (alle fire) var ejere af det. Hun kunde ikke tro at have enten en dybere forståelse af, eller et nøjere kendskab til min faders litterære virksomhed end f. eks. jeg. Og hun kunde ej heller tro at være i besiddelse af større pietet for hans forfattervirksomhed eller bedre indsigt til at forestå udgivelsen end jeg var $\mathrm{i}$ besiddelse af.

Jeg henstillede det hele forhold til hendes samvittighedsfulde overvejelse og krævede ikke noget svar nu; men jeg bad hende at lade mig vide sin mening, når hun selv havde overvejet sagen og rådført sig med hvem hun havde tillid til.

Hun takkede mig for min venlige oprigtighed og lovede at tage sagen under overvejelse.

Den 2 Ide september tilskrev jeg fru G. for at mælde min hustrus ankomst til Montreux og tilføjede et par ord om, at jeg afvæntede hendes mundtlige svar. Jeg skulde ikke bringe sagen på bane, før hun selv fandt det belejligt.

Den 26de Sept. var jeg ude på Tuborg, for at efterse faders papirer, navnlig for sammen med fru G. som hele tiden var i besiddelse af alle nøgler til hans gemmer, at se efter, om et testamente skulde findes, som hun dagen efter hans død havde sagt, at han en gang havde omtalt. Skifteretten vilde efter sædvane straks have forseglet alle papirer; men Johan gik dengang i borgen for, at alt skulde blive efterset, om testament deri skulde findes. Vi fandt intet. 
Hun var meget venlig mod mig, men bragte ikke min sag på bane, og jeg altså heller ikke.

Den 28de Sept. var jeg atter på Tuborg for at fuldende eftersynet, sammen med fru G. Da sagde hun, at nu vilde hun svare mig på, hvad jeg forleden havde sagt hende. Hendes svar bestod i at vise mig et brev fra prokurator Rothe $^{3}$ ), som er kurator i boet, hvori han på hendes forespørgsel om den litterære ejendomsret svarer hende, at den efter hans og skiftekommissjonens mening efter loven må tilkomme hende. Hun ytrede intet om nogen højere ret end lovens bogstav, men tilføjede, at som en følge heraf vilde hun også have den hele hende efter loven tilkommende ret. Men hun vilde aldrig kunne glemme, at var der nogen enkelt mand, der både ved kendskab og kærlighed var knyttet til G.s forfattervirksomhed, så var det Svend Gr. som derfor måtte være nærmest til alt hvad der angik udgivelsen. (Eller sådan noget lignende.) Jeg spurgte hende, hvad hun regnede til G.s efterladte håndskrifter, der ifølge den litterære ejendomsret skulde tilfalde hende efter loven, og hun svarede: alt. Jeg spurgte hende, om hun da også mente at have eneret til alle faders breve, så at f. eks. breve fra min moder til min fader var hendes ejendom. Hun mente ja. Da sagde jeg i al venlighed, at dette ikke var vor mening og sikkerlig heller ikke lovens, så selv om den rent litterære ejendomsret efter lovens bogstav måtte tilkomme hende, så gjaldt det dog ikke om sådanne papirer, som ikke var til trykken bestemte skrifter, om hvilke loven alene handler. Og dersom hun fastholdt sin fortolkning, så vilde det blive nødvendigt, at vi søgte sagen klaret ved domstolene; i det jeg tilføjede, at en sådan prøvelse efter min mening ikke behøvede eller burde få indflydelse på det venlige forhold imellem os, som jeg håbede bevaret. Hun handlede efter min formening ikke ret og billigt; men jeg drog ikke $\mathrm{i}$ tvivl at hun trode at gøre det. Og samme tro måtte hun have om os, der mente, at det var vor pligt ikke mindre end vor ret at hævde os den myndighed over vor faders efterladenskab, som tilkom os. (Jeg havde d. 26de været troskyldig og tossegod nok til at vise hende og henlede hendes opmærksomhed på de yderst mærkelige optegnelser fra faders ungdom, som fandtes mellem hans papirer. Også dem mente hun nu at have udelukkende ejendomsret til.)

Vi gik efter denne samtale, som førtes i al venskabelighed til fortsættelsen af vort arbejde, i det jeg under hendes øjne gennemgik og bundtede alle løse papirer og breve og indlagde dem i skabe og bordskuffer, hvortil hun beholdt nøglerne. Der stod i Vartov et skrivebord, om hvilket fader havde sagt, at deri skulde findes noget til Frederik ${ }^{4}$. Vi blev da enige om endnu sammen eftermiddag (jeg spiste der til middag) at køre ind sammen og efterse skrivebordet. De 4 skuffer i dette indeholdt intet testament og ej heller noget til Frederik. Den midterste 5te var tilbage, men den kunde ikke åbnes med nogen af de medbragte nøgler. Hun sagde, at den rigtige nøgle måtte findes hjemme; jeg sagde da, at når hun dagen efter (som da bestemtes) lod skrivebordet hente hjem til Tuborg, kunde hun jo selv se efter, om der var noget

3. prokurator Rothe ग: Peter Rothe $(182 \mathrm{I}-76)$, som bl.a. var Skifterettens inkassator $\mathrm{i}$ alle mindre boer.

4. Frederik 0: Frederik Lange Gr., (1854-1903), søn af N.F.S. Gr. i dennes andet ægteskab. 
af det vi søgte, og så binde det sammen hvad der ellers fandtes af papirer og breve. - Da vi var færdige hermed, spurgte hun, om jeg ikke havde lyst til at se hendes nye lejede lejlighed på ny $\left.v^{5} j^{5}\right)$. Det vilde jeg nok og vi kørte der ud, at bese den. På vejen talte vi videre om faders skrifter og deres udgivelse. Hun gjorde mig adskillige spørgsmål, som hun fandt sig tilfreds med besvarelsen af, og jeg bemærkede: ja, om vi end ikke er ganske enige om, hvem der skal lede de videre skridt, så er vi dog enige om det første: at gemme og frede om alt skriftligt, som findes efter fader. (Det kan bemærkes, at jeg oppe i det øvre bibliotek, hvor der stod et skab med gamle breve, og som ellers havde været legestue for hendes børnebørn, fandt mellem deres legetøj og børnebøger, dels hele brevpakker, dels enkelte manuskripter f. eks. et udkast til et langt og vigtigt brev fra fader fra hans tidlige tid alt udfaldet af det nævnte skab. Jeg reddede, hvad der fandtes og fik det ind i skabet, som fru G. fik nøglen til, og alle hendes nøgler fik jeg på et knippe $\mathrm{i}$ hendes værge. Uagtet fru $\mathrm{G}$. således krævede sin ret til det yderste og endog i fortolkningen gik ud over alle grænser, så var vort hele forhold særdeles venskabeligt, og jeg håbede, at der vel vilde kunne træffes en mindelig og venlig overenskomst imellem os.

Det var jo rigtignok påfaldende, at hun den 6te Oktober havde konfirmatjon, hvortil var budet selskab, men ingen af os brødre havde fået så meget som en underretning om dette. Men lignende hensynsløsheder var vi så godt vante til fra den side, at jeg ikke deraf turde udlede noget bestemt ugunstigt sindelag.

Den 8de Oktober var jeg om aftenen hos Brandts ${ }^{6}$ ). Da jeg kom hjem fandt jeg en seddel fra borgemester Schjørring ${ }^{7}$ ) fra Skælskør, der som rigsdagsmand var i byen $\mathrm{i}$ de dage. Vi skulde snart efter mødes hos Fenger i salmekomité8), og nu bad han mig se op til ham i 3 hjorter $^{9}$ ) en time forinden da han meget ønskede at tale med mig. Jeg kom som bestemt. Han havde da dagen forud efter fru G.s indbydelse været på Tuborg, og hun havde bedet ham tale med mig for at få en overenskomst i stand angående den pågældende sag. Hendes forslag, som hun gennem ham rettede til mig, gik ud på, at hun vilde overgive alle Grundtvigs papirer i mit værge, for at jeg skulde på hendes vegne gøre fortegnelse over dem og gøre forslag til udgivelse, ligesom hun også vilde antage mig til udgiver af dem, undtagen af hvad der skulde gives ud af prækener og lignende sager, hvortil hun

5. ny vej 0 : Nyvej nr. Io, Frederiksberg, hvortil hun flyttede hen efter Gr.s død.

6. C. J. Brandt ( $1817-89$ ), præst og litteraturhistoriker; blev Gr.s efterfølger som præst i Vartov.

7. G. P. C. Schjørring (1831-1913), cand. jur., politiker, folketingsmand, i nogle år borgmester i Skelskør, senere i Kolding, se iøvrigt Dansk biogr. Leksikon.

8. salmekomité ऽ: den komité, der varetog udgivelsen af den samlede udgave af Gr.s salmer, og hvoraf bl. a. Sv. Gr. og pastor P. A. Fenger var medlemmer.

9. 3 hjorter ๑: det dengang bekendte gæstgiversted »Tre Hjorter«, Vestergade 12. 
vilde have andres (formodentlig Brandts og Helvegs) bistand. Det var åbenbart meningen, at jeg skulde lønnes af hende for disse arbejder.

Jeg sagde da Schjørring, at så megen pris jeg end satte på den tillid fru G. herved viste mig personlig, så kunde jeg dog ikke på det nærværende trin af sagen, hvor jeg var optrådt på altid tre voksne søskendes vegne, skille min sag fra deres og så at sige gå over i hendes lejr.

Schjørring sagde dertil, at han meget godt kunde forstå dette, men fortsatte nu forhandlingen, i det han vel indrømmede, at der var en meget væsentlig moralsk forrettighed for os til at betragte os som vor faders arvinger m. h.t. hans litterære efterladenskab; men når fru G. vilde påkalde loven, så tilfaldt den litterære ejendomsret hende og først efter hendes død hans børn. Den udstrækning hun vilde give denne ret til alle biografiske papirer og breve, var overdreven, og det vilde han lade hende vide.

Efter en del tale kom vi da over ens om det forslag, som han varmt vilde anbefale hende: at alle G.'s håndskrifter, og ligeledes den litterære ejendomsret, skulde efter et tilbud af hende indgå i det fælles bo, således at der indtrådte sameje efter de almindelige regler: hun halvdelen, den anden halvdel til lige deling mellem alle G.s børn. Han lovede at fremhæve for hende at billigheden talte herfor og at hun udtrykkelig måtte udtale dette i det brev, som han vilde foreslå hende at skrive til os, og som vi så skulde besvare. Skulde der endnu gives differenspunkter, kunde de udjævnes gennem korrespondance, og derefter vilde han anbefale, at vi til sammen underskrev en overenskomst.

Det var den gde Oktober. S. skulde dagen efter rejse hjem, men vilde straks tilskrive fru G. herom. D. I Ite allerede tilskrev han fru G. et brev, som jeg ikke kender. Hun svarede ham først Io dage efter den 2 Ide i et brev, som, skønt stilet til ham er bestemt for os. Dette brev er åbenbart skrevet af en jurist, og hun har da efter at have følt sig utilfreds med Schjørrings råd henvendt sig til den samme Juel ${ }^{10}$ ), som var hendes prokurator ved købet og salget af stedet på Gl. Kongevej, hvor hun ikke havde grund til at være altfor tilfreds med ham. - Fru G. sender brevet til Schj. åbenbart fordi hun ikke vil, som han havde rådet og forudset, forhandle direkte med os. Dette uhyggelige aktstykke lyder som følger (understregninger i det ere her tilføjede).

Her tør dog forud for dette aktstykke gives den historiske oplysning, at under 7 de Oktbr. tilskrev fru G. mig et venskabeligt brev (»Kære S... Deres hengivne.), hvori hun beder Johan og mig en af dagene i ugen komme ud til hende, for at fordele G.s efterladenskaber, som vi kunde ønske at have til erindring. Vi kunde først bestemme mødet til den I2te. Vi vare aldeles forbausede over at se hendes holdning ved denne lejlighed. Jeg havde jo ikke set hende siden d. 28de Septbr., da hun kørte mig ud at se sin lejlighed, hvilket jo altsammen var så meget venskabeligt. Vel havde hun ignoreret os ved konfirmatjonen $d$. 6te, men brevet af 7 de var venligt. Jeg havde intet

ı. Juel э: juristen og politikeren Christian Juel (I828-1914), se Dansk biogr. Leksikon, hvor også er omtalt Juels spekulation i et sjællandsk jernbaneanlæg (næunt senere i Sv. Gr.s beretning). Med »stedet på Gl. kongevej《 menes Gl. Kongevej I 48, hvor Gr. boede I 859-67. 
hørt fra hende om den skuffe i faders skrivebord i Vartov, som jeg overlod hende at åbne, og hvori vi væntede at finde noget, i alt fald til Frederik, og da han syntes at have betragtet den som et særligt gemmested måske også det savnede testamente. Jeg kom da nok så venlig og bød god aften og spurgte hende, om der så blev fundet noget $\mathrm{i}$ den skuffe. Dertil svarede hun kort og stift: Nej. (Det var hvad jeg fik for min tillid, og jeg [havde] ikke en gang fået så meget, om jeg ikke havde spurgt.) Så rejste hun sig stiv og kold som en stenstøtte og sagde: skal vi så gå ind - nemlig i første stue, hvor de sager, der kunde være tale om var fremlagte. Elisabet ${ }^{11}$ ) og broder Frederik vare tilstede. Fordelingen, som jeg har berettet om, gik for sig under venskabelig form, men under hendes iskolde behandling. Hun var åbenbart utilfreds med, at Johan gjorde fordring på pokalen ${ }^{2}$ ), som hun vilde have opbevaret for en frikirke, (skønt i så fald det, der gav den værd, hele indskriften måtte udslettes.) Endnu mere utilfreds var hun ved, at vi gjorde fordring på, at et af os børn skulde udløse af boet det billed af Udby, som hang over sofaen. Hun vilde have det, sagde hun, og da vi gjorde opmærksom på, at det var et afgjort familiestykke: den kirke, hvor fader var døbt, og hvor hans fader havde virket i henved 50 år, så kom det frem, at hun vilde have testamenteret det til Frederik. Jeg sagde da til Frederik (uden at spørge ham om han vilde afstå hvad han ingen ret havde til): du har da vist intet imod at det er mit, mens jeg endnu lever. Han sagde, at det var ham lige kært, hvem af os brødre der havde det. Det blev da sat på min konto. Da forretningen var endt, bad hun os ikke blive til te, men bad os tage sagerne med os og det lod næsten som om de ikke måtte blive der længere. $\mathrm{Da}$ vognen skulde ind til byen efter $\mathrm{Asta}^{13}$ ) (det var øsende vande) fik vi lov at køre i den med vore pakkenilliker op til Meta, hvor Mina var ${ }^{14}$ ). $\mathrm{Vi}$ vare alle lige forbavsede over hendes opførsel. $N u$ kan jeg se sammenhængen. Den 7 de da hun skrev mig til, havde hun jo netop sendt bud efter Schjørring. Ved hans mægling havde hun tænkt at vinde mig og derved forpurre alle planer til modstand mod hendes enevældige besiddelsestagen af alle faders papirer. Ved Schjørrings brev af i Ite, som hun har fået den I2te morgen, og om hvilket hun formodentlig allerede har forhandlet med sine betrode rådgivere, blandt hvilke uden tvivl $\mathcal{f u e l}^{15}$ ) ( $\bmod$ hvem Johan kort forud i god tro havde advaret hende, da hun talte om at tage ham til prokurator

I I. Elisabet 0: Elisabeth Grundtvig (I856-I945), datter af Gr.s søn Johan Gr. Hun var forkæmper for kvindesagen, litterat, oversætter.

1 2. pokalen. Antagelig den store sølvforgyldte pokal, som Gr. på sin 50-årsdag i 1833 fik foræret (med en rulle dukater i) af sine tilhørere i Christianskirken. Formidleren ved denne gave var J. Chr. Lindberg. jf. Gr.s brev til ham (i Breve II ( I 926 ), s. 226).

13. Asta ว: Gr.s og Asta Gr.s datter, den i 1860 fødte pige Asta Marie Elisabeth Frijs Gr. Hun blev i i88 I gift med professor og overlæge, dr. med. Kristian Poulsen.

14. Meta og Mina. Gr.s datter Meta (1827-87) var i 1847 blevet gift med pastor P. O. Boisen, der døde i I 862. Meta Boisen boede Højbroplads 2 I. Mina, kaldenavn for Vilhelmine Gr. (f. Stenersen), var gift med Gr.s ældste søn, arkivar i Rentekammeret Johan Gr. (1822-1907).

15. Juel, se note ro ovenfor. 
igen til salget af Tuborg, eftersom det var gået noget underligt til med salget af stedet på Gl. Kongevej, hvor Juel nok var halvt med den mand, han rådede fru G. til at sælge stedet til; og halvt om at parcellere det ud til det dobbelte af den pris, han rådede hende at sælge for, og jeg har efter Juels jærnbanehistorie ikke kendt ham, når vi mødtes på gaden, mens vi tidligere var på hat og på jævnlig tilfældig samtale sammen.) Ved Schjørrings brev er hun bragt ud af denne forhåbning og finder $\mathrm{i}$ den sted et forslag fra ham om at gå på forlig og dele sin myndighed over alt Gr.s litterære efterladenskab med hans børn. $S a$ antager hun en helt anden holdning imod os, som forklarer det usigelig uhyggelige møde $i$ faders stue den inte om aftenen.

$\mathrm{Nu}$ det brev, som fru G. den 2 Ide sendte Schjørring:

\section{II}

Store Tuborg den 2 Ide Oct. 1872.

\section{Kære Schjørring $\left.!^{16}\right)$}

De kan nok tænke, at jeg har taget Deres Brev af i ite ds med det Forslag, det indeholdt, under alvorlig Overveielse, ligesom jeg ogsaa har raadført mig med gode Venner om min hele Stilling og særlig om mit Forhold ligeoverfor Grundtvig's Børn med Hensyn til Forlagsretten.

Jeg er nu kommen til en endelig Beslutning og sender Dem dette Brev, for at meddele Dem den.

Hvad De sagde mig, at Forlagsretten saavel til de af Grundtvig efterladte utrykte Sager som til nye Udgaver af hans Bøger er min Eiendom, saalænge jeg lever, er bleven bekræfted af dem, med hvem jeg har raadført mig.

Denne min Eiendomsret vil jeg hverken opgive eller dele med Nogen, og kan derfor ikke gaae ind paa de Forslag, som Professor Grundtvig gjennem Dem har gjort mig; men paa den anden Side føler jeg, at Billighed taler for, at Grundtvigs Børn ogsaa i min Levetid faaer Deel, ikke alene i det Udbytte, som Udgivelsen af hans Skrifter maatte bringe, men ogsaa i selve Udgivelsen. Jeg vil derfor dele Udbyttet med dem, saaledes at Halvdelen deraf tilfalder mig, Halvdelen alle Grundtvig's Børn til lige Deling imellem dem, og jeg vil raadføre mig med Grundtvig's Børn om Valget af det, der skal udgives, for saa vidt de er modne nok til derom at kunne have en Mening; Jeg ønsker at forhandle med dem om Valget af, hvad der skal udgives, saavelsom om Udgivelsesmaaden igjennem en Befuldmægtiget, men er

I6. Dette brev gengives som før nævnt direkte efter originalen. I sin gengivelse af brevet har Sv. Gr. understreget adskillige ord og hele linier og har tilføjet et par fodnoter som følger: Til ordene »som Udgivelsen af hans Skrifter maatte bringe« har Sv. Gr. sat følgende fodnote: Fru G. véd, at dette vil blive = intet, under hendes bestyrelse, da hun nylig til Tredjemand har sagt, at hun vel var enig med mig om udgivelsesmåden, men uenig $\mathrm{i}$, at jeg ikke, som hun, vilde gøre dem så billige som muligt $\mathbf{0}$ : uden forfatterhonorar, altså uden udbytte, at dele. (S. G.). - Til det af Asta Gr. understregede ord alle føjer Sv. Gr. i sin afskrift flg. fodnote: sål. udhævet af brevskriverinden. 
iøvrigt sindet, navnlig med Hensyn til Udgivelsen af de videnskabelige og verdslig »poetiske Skrifter«, at vise den største Imødekommen mod de Ønsker som maatte blive fremsatte af dem.

Hvad Gjennemsynet af Manuskripterne angaaer, saa lader jeg $\mathrm{Hr}$. Assistent Weeke $^{17}$ ) fra det kongelige Bibliothek optage en Registratur over dem, og de vil da af mig efterhaanden blive udleveret til Børnene til Gjennemsyn.

Det er nu mit Ønske, kjære Schjørring, at De vil meddele Grundtvig's Børn af første Ægteskab dette mit Tilbud, og hvis De finder det hensigtsmæssigt, maa De gjerne lade Dem see dette Brev.

Jeg venter snart at høre fra Dem og beder Dem og Deres Kone modtage en venlig Hilsen fra

Deres hengivne

A. Grundtvig.

Schjørring sendte mig dette aktstykke med et brev så lydende:

Skælskør 23 Oct. 1872.

Efter den med Dem trufne Aftale tilskrev jeg Fru Grundtvig, at De for Deres Vedkommende vilde være villig til at gaa ind paa et Tilbud fra hendes Side om at etablere et Fællesskab med Hensyn til Udgivelsen af Deres Faders efterladte trykte og utrykte Skrifter, saaledes at hun havde samme Stemmeret ved alle opstaaende Spørgsmaal som Arvingerne tilsammen og tog Del i Udbyttet lig med Arvingerne tilsammen. Jeg tilraadede hende meget indstændig af Billighedshensyn at gjøre et saadant Tilbud, og gjorde hende endelig ogsaa opmærksom paa det Ønskelige i, at Manuskripterne snart kunde overgives Dem til Gjennemsyn, da Udgivelsen af Salmerne beroede derefter.

Jeg har derpaa modtaget et Svar fra Fru Grundtvig, som jeg efter hendes Anmodning tilstiller Dem. Hun betoner rigtignok noget stærkt sin Eiendomsret ligeoverfor Deres og Deres Søskendes raadgivende Myndighed, men jeg anser det $\operatorname{dog}$ for givet, at i Virkeligheden vil et Fællesskab, saaledes som det ovfr. antydede, tilveiebringes efter dette $\left.B^{*}{ }^{*}\right)$, og jeg tillader mig derfor at anbefale hendes Tilbud til velvillig Modtagelse af Dem og Deres Søskende, for at en uhyggelig Strid kan blive undgaaet. Jeg vil ganske henstille til Dem, om De vil lade den videre Forhandling i denne Sag gaa over Skælskør eller sætte Dem i direkte Forbindelse med Deres Stifmoder.

Ærbødigst og venligst

Til

Schjørring.

Hr. Prof. Grundtvig.

*) 》Den Befuldmægtigede« vil jo nemlig naturligvis blive Dem, da Ingen kan være bedre skikket til at forestaa Udgivelsen.

I7. Weeke o: underbibliotekar ved det kgl. Bibliotek G. Weeke (1832-1905). Om ham, se Dansk biogr. Leksikon. Han havde i 187 I medvirket ved udgivelsen af Gr.s »Kirke-Speil«, idet denne bogs egentlige udgiver, Kr. Køster, døde, mens trykningen stod på. 
Schjørrings forudsætning: at den omtalte befuldmægtigede skulde være mig, er ganske urigtig. Jeg fik trykket ud af Weecke, med hvem fru G. havde talt om sagen, og som havde set hendes ultimatum før det afsendtes (han forsikrede, at han havde ingen del i det, og han beklagede, at hun benyttede den hjælp dertil, som hun havde haft, som han kendte, men ikke turde nævne), at hun udtrykkelig havde sagt ham, at hun kunde og vilde om disse sager $i k k e$ forhandle direkte med mig. »Den befuldmægtigede« kunde herfter kun være enten en kommissarius udnævnt af fru G. eller en minister, som vi fik akkrediteret hos hende.

Efter moden overvejelse mellem os tre søskende, udfærdigedes til Schjørring følgende svar, som på grundlag af et udkast fra min hånd, som var meget skrapt, er udarbejdet væsentlig af Johan. Det er dateret d. $26 \mathrm{de}$ men først afsendt d. 27 de aften.

Kjøbenhavn og Frederiksberg d. 26de Oktb i872.

Hr. borgemester Schjørring.

I det jeg på mine helsøskendes og egne vegne takker Dem særdeles meget for den venlige og velvillige måde, hvorpå De efter bispinde Grundtvigs anmodning har søgt at bringe en mindelig overenskomst til veje angående vor afdøde faders litterære efterladenskab, skal jeg ikke undlade at svare Dem med al den oprigtighed og ligefremhed, som De har krav på af os.

$\mathrm{Vi}$ have alle tre i lige grad følt os smertelig overraskede ved den mildest talt uvenlige holdning, vor faders enke ved denne lejlighed har indtaget imod os. Vi have hidtil ikke vidst rettere, end at vi stode på en god og hjærtelig fod med hende, vi ere os bevidste altid at have vist hende kærlighed og agtelse, og vi have nu efter vor faders død vist hende den ubetingede tillid at lade hende være i enebesiddelse af alle hans papirer, uagtet der mellem disse måtte formodes at findes en testamentarisk bestemmelse.

Ikke mindre pinlig overraskede ere vi blevne ved at se den form, som de billige og rimelige forslag, hvorom De den gde dennes mundtlig forhandlede med mig, nu har erholdt i det brev fra bispinde Grundtvig af 2 Ide Oktober, som De efter hendes anmodning har tilstillet mig.

Det ny forslag er nemlig af den beskaffenhed, at vi intet øjeblik have kunnet tænke på at modtage det, eftersom det er aldeles betydningsløst, og vi ikke derved vilde få mindste udsigt til at kunne gøre nogen som helst indflydelse gældende med hensyn til udgivelsen af vor faders skrifter, hvilket selvfølgelig var det, som lå os på sinde.

I steden for en sådan virkelig om end begrænset indflydelse, bydes os her kun et ubestemt tilsagn om den største imødekommen mod de ønsker, vi vel at mærke, gennem en mellemmand - måtte fremsætte til fru Grundtvigs endelige afgørelse. Vi finde denne os tiltænkte stilling ganske værdiløs og derhos særdeles ydmygende, og vi holde os med god grund forvissede om, at vor afdøde fader aldrig har tænkt sig muligheden af, at der vilde kunne blive budt hans børn en sådan stilling lige over for hans litterære efterladenskab, 
til hvilket vi formene os at besidde en moralsk, om end ingen juridisk ret, og som ikke nogen er berettiget til at tvivle om, at vi jo vilde vide at holde tilbørlig i ære.

Vi kunne derfor efter moden overvejelse aldeles ikke gøre andet end at forkaste dette forslag. Bispinde Grundtvig får så at råde med vor faders litterære efterladenskab, som hun tror at kunne forsvare mod hans minde, mod hans børn og mod fædrelandet.

I det jeg i henhold til vor samtale antager det for en selvfølge, at her kun er tale om vor faders allerede udgivne eller dog til trykken bestemte skrifter og slet ikke om alle papirer og optegnelser af væsentlig biografisk interesse eller om breve til den afdøde, hvilke sager utvivlsomt må henhøre til det samlede bo, beder jeg Dem herved på mine to helsøskendes og egne vegne om at meddele bispinde Grundtvig denne skrivelse, i det jeg endnu en gang bringer Dem vor tak for Deres forhold i denne sag.

Deres venligst og ærbødigst forbundne

Svend Grundtvig.

Denne fællesskrivelse ledsagedes af følgende privatbrev fra mig til Schjørring.

Kære Schjørring!

Frederiksberg 27/10 I872.

Vedlagte for fru Grundtvig bestemte brev, som i følge hendes skrivelse til Dem ikke kunde gå nogen anden vej end om af Skælskør, da hun jo udtrykkelig siger, at »hun vænter snart at høre fra Dem«, - er udarbejdet og vedtaget af os tre søskende tilsammen, skønt det går under mit navn, fordi meddelelsen var stilet til mig.

Jeg kan ikke sige Dem, hvor dybt det går mig til hjærte, at et sådant forhold skulde udvikle sig mellem vor faders enke og hans voksne børn, som ikke havde nogen anelse om tilstedeværelsen af så ukærlige følelser, som hendes brev unægtelig bærer vidne om. Det er mig en hjærtesorg som søn og som kristen, at noget sådant skulde komme frem straks efter faders død. Noget af det bitre og sårende $\mathrm{i}$ brevets form kan vel med rimelighed tilskrives den ukendte rådgiver, som har konciperet det, og som jeg formoder ikke er nogen anden end hendes prokurator, forhenværende appellatjonsretsråd og senere jærnbanekoncessjonsspekulant Juel; men hun kunde dog aldrig have afskrevet og underskrevet det, uden væsentlig at dele den uvenlige følelse, hvorom det helt igennem bærer vidne.

Det mest krænkende i forslaget er jo bestemmelsen om »en befuldmægtiget«, hvilket De - hvad jeg godt kan forstå - har vægret Dem ved at opfatte efter ordlyden, i det De tænkte Dem mig som denne mellemmand. Men deri tager De storlig fejl; selve ordene $\mathrm{i}$ forbindelse med brevets hele tone vise det modsatte, og jeg véd desuden fra anden kilde, at det netop er fru Grundtvigs tanke, at hun ikke vilde forhandle direkte med nogen af os søskende om faders litterære efterladenskab, og det endskønt hun for nylig sagde mig, at hun vidste (hvad vel flere vide), at man skulde lede længe, før man fandt 
nogen anden mand, der med den fornødne litterære dannelse forbandt så stor en fortrolighed med de pågældende skrifter og så varm en kærlighed til min faders hele skribentvirksomhed, som netop jeg, hvem han desuden selv i en række af år benyttede som hjælper og mellemmand ved udgivelsen af sine skrifter. - Men den gang hun sagde mig noget sådant, da havde hun jo tænkt at kunne få mig til at skille min sag fra mine søskendes; ti det forslag, hun ved Dem gjorde mig, og som De godt kunde forstå at jeg ikke kunde gå ind på, det fremtræder nu, efter hvad siden er passeret, for mig i et uhyggeligt lys: som et forsøg på at købe mig.

Efter således at have ret forstået dette med »den befuldmægtigede«, vil De da, tænker jeg, umulig kunne tilråde os at gå ind på hendes nye forslag, men må erkende det berettigede og selvfølgelige $i$, at vi måtte frasige os den latterlige og uværdige rolle: gennem en fremmed, en ambassadør, som Grundtvigs børn skulde søge ansat og modtagen hos deres faders enke, at udtale deres »råd « angående bestyrelsen af hans litterære efterladenskab. En rådgivende forsamling altså, med ret til gennem en mellemmand at forebringe sine ønsker for en myndig selvhersker, der tilmed have andre og mere betroede rådgivere, dette er den lidet misundelsesværdige stilling, som tilbydes os.

Den litterære ejendomsret over Grundtvigs skrifter kunne vi vistnok ikke juridisk gøre fru Grundtvig stridig, om det end både har undret og smertet mig, at hun, som vil være en kristen kvinde, kan lade sig således forblinde af selviske og selvrådige lyster, at hun ikke kan erkende, at det kun er lovens bogstav, der hjemler hende denne ret, medens billigheden - da hun ikke kan beråbe sig på noget formodet ønske eller vilje hos vor afdøde fader - måtte byde hende $\mathrm{i}$ alt fald at dele denne ret med Grundtvigs børn og arvinger.

Men vi kunne da under ingen omstændigheder tilstede hende at give denne sin juridiske ret en ulovlig udstrækning til alle faders biografiske og private papirer, så at hun skulde (som hun mener) være enerådig f. eks. over alle breve til ham også fra os selv og fra vor afdøde moder, eller over dagbøgerne fra hans ungdom, så vel som over for farfaders og oldefaders papirer. Hun har jo nu allerede, som mældt $\mathrm{i}$ hendes skrivelse, krænket vore naturlige rettigheder og tillige efter vor mening forgrebet sig på den pietet, hun er den store afdøde skyldig, ved med forsætlig forbigåelse af hans børn at antage en fremmed til at gennemgå alle hans papirer. Hun har endogså udtrykkelig forbudt Weecke at lade os blive vidende om den ham givne kommissjon, som kun ad anden vej er kommen til vor kundskab, før den omtales i hendes brev. Hvad borger os nu for, at hun, som nu står i begreb med at flytte fra Tuborg, ikke lader alle faders papirer flytte bort, vi vide ikke hvorhen? Måske det kunde være hendes agt at deponere dem hos sin før omtalte prokurator.

De vil da, håber jeg, ikke finde det uberettiget, når vi fra vor side gøre skridt til, at alle faders papirer snarest muligt kunne komme i sikker forvaring, indtil en overenskomst med hensyn til dem kan bringes tilveje.

Det er stygt, at der skal rejses en sådan uhyggelig strid over oldingens grav; men ansvaret derfor falder på den, fra hvem forargelsen kommer.

Deres taknemlige og tillidsfuldt hengivne

Svend Grundtvig. 
Det skridt, hvortil der sigtes i slutningen af dette brev, er en af Johan på egne og vore vegne i retten nedlagt og af den antagne fordring om, at alle papirer beslaglægges under rettens segl, indtil overenskomst er truffen, da det er givet, at en meget stor del af disse papirer, som af fru Gr. ere tagne i enebesiddelse, er det samlede bo, altså også den afdødes børn, tilhørende. Johan vil være tilstede ved denne forretning, der vil blive foretagen en af disse dage.

Mandagen d. 28de Oktbr. er desuden til kommisjonen indgivet følgende skrivelse:

\section{Til}

hof- og stadsrettens skiftekommisjon.

Den i vor afdøde faders, biskop N. F. S. Grundtvigs, bo beroende, ham ved hans præstejubilæum år I86ı skænkede syvarmede guldlysestage er en genstand, der, skønt uden synderligt kunstværd, dog måtte ønskes bevaret, som et minde om sin ejermands lange og betydningsfulde virksomhed i og for den danske kirke, så vel som om den påskønnelse heraf, for hvilken gaven var et udtryk. Dette ønske deles ganske vist af samtlige arvinger; men der er hidtil ikke fremkommet noget forslag til formen for denne genstands bevarelse, som har kunnet vinde alle vedkommendes bifald.

Vi undertegnede, Grundtvigs børn af første ægteskab, tillade os herved for den høje kommisjon til videre behandling at fremsætte et forslag til en anbringelse af nævnte lysestage, som efter vor formening på en smuk og værdig måde vilde sikre dens bevarelse for fremtiden, give den en med dens oprindelse og form stemmende kirkelig anvendelse og tillige $\mathrm{i}$ flere henseender minde om den afdødes virken for den danske kirke og det danske folk.

Vi foreslå nemlig, at den nævnte lysestage af alle N. F. S. Grundtvigs arvinger, med justitsministeriets minde, for så vidt sådant udkræves, skænkes til Roskilde domkirke, under forudsætning af, at denne vil modtage og bevare den og tage den i brug på kirkens højalter. Til begrundelse af dette forslag skulle vi anføre følgende:

Flere af landets domkirker ere efter forlydende allerede i besiddelse af og anvende på alteret lignende syvarmede lysestager, ligesom denne efterligninger af den i 2den Mosebog, 25de kapittel beskrevne, der antages at være bleven bevaret i Jerusalems tempel lige til dettes forstyrrelse, og derefter at være bortført til Rom, hvor en afbildning af den findes på et af reliefferne i Titus' Triumfbue. Der vilde altså ikke være noget upassende eller usædvanligt ved den foreslåede anbringelse.

Roskilde domkirke er både den gamle hovedkirke i det stift, i hvilket N. F. S. Grundtvig virkede som præst $\mathrm{i}$ over $6 \mathrm{I}$ år, som fader og farfader før ham, og den er tillige at betragte som et dansk historisk mavsoleum, der gemmer støvet så vel af »Bisp Vilhelm og kong Svend«, af Saxo og dronning Margrethe som af Kristjan den fjærde og Frederik den syvende. Og der savnes ej heller for vor faders vedkommende en mere særlig tilknytning til denne kirke. I den til samme hørende Landemodessal oplæste han år I81 2 en del af sit store og mærkelige digt Roskilde-rim, der tillige med Roskilde-saga (bægge 
udgivne I8I4) beskuer og besynger Roskilde domkirke som det synlige symbol for Danmarks både folkelige og kirkelige levnedsløb.

Vi tro derfor ikke, at det vil være muligt, at påvise en mere værdig monumental plads for den omhandlede guldlysestage, end denne kirkes alter ${ }^{18}$ ).

Kbhn. d. 27. Oktbr. 1872.

$$
\text { Ærbødigst }
$$

Joh. Grundtvig. Svend Grundtvig. Meta Boisen f. Grundtvig.

Den foran omtalte sikring af faders samtlige papirer fandt sted onsdagen d. 3ote Oktbr. da skifterettens fuldmægtig indfandt sig kl. Io form. på Tuborg for efter rettens ordre at forsegle og medtage alle papirerne. De vare da pakkede i kasser af Weecke. Fru Gr. havde spurgt Weecke, om han kunne modtage dem i sin bolig, medens hun rejste io dage til Jylland. Han turde ikke have dem hjemme, men fik af justitsråd Brun $^{19}$ ) tilladelse til at de på fru Gr.s vegne måtte opbevares på det kgl. bibl. medens hun var bortrejst. De bleve nu i steden for tagne i forvaring på Rådhuset i Skifterettens lokale. Fru G. vilde om onsdagen rejst til Jylland. Hun opsatte nu rejsen til næste dag og var om onsdagen hos pastor P. Fenger for at beklage sig. Fenger var hos mig torsdag aften, og vi talte venlig og udførlig om sagerne. Han fandt Schjørrings forslag rimeligt og håbede, at det vilde blive antaget, når fru Gr. kom tilbage. Det var, sagde han, hendes tanke med »den befuldmægtigede«, at denne udnævntes af hende for at handle på hendes vegne. Hun havde tænkt på Brandt eller Helveg. Derimod kunde vi intet have, sagde jeg, når hun ikke vilde ændre den rådgivende til en medbestemmende ret for Gr.s børn.

Hermed ender Svend Grundtvigs skildring af de dramatiske begivenheder omkring håndskrifterne. Ved at true med en proces og ved (som en begyndelse dertil) at lade håndskrifterne beslaglægge lykkedes det altså Grundtvigsønnerne at få klarhed over det prekære spørgsmål om fru Astas »befuldmægtigede«. Det viste sig, at hun havde tænkt på enten pastor C. J. Brandt ved Vartov eller pastor Ludvig Helveg i Odense. Da Brandt og Sv. Gr. var nære venner, bortfaldt dermed hele grundlaget for aktionen, og der åbnedes en vej for en endelig ordning.

Derefter skete følgende. Fru Gr. udsatte sin rejse til Jylland endnu nogle dage, og via en mellemmand, nemlig hendes veninde frk. Filippine Larsen, henvendte hun sig den 5. nov. skriftligt til Sv. Gr. med følgende lille brev:

18. Gr.s syvarmede lysestage kom ikke til Roskilde, men til Frederikskirken (Marmorkirken) ved dennes indvielse i 1894.

19. Brun 5: overbibliotekar, justitsråd Chr. Bruun, chef for det kgl. Bibliotek. 
Hr. Professor Grundtvig.

Lille Vrå d 5te November

Fru Grundtvig har bedt mig sige Dem, at hun under sin fraværelse gerne vilde have manuskripterne $\mathrm{i}$ sikkerhed på det kongelige bibliothek, hvilket der forhåbentlig ikke kan være noget til hinder for. Hvordan hun skal få det ordnet er hun ikke ret på det rene med men har tænkt, at det måske var rigtigst at henvende sig til Veke.

Fru Gr siger, her findes en dagbog, som hun gerne vil bede Dem gemme, hvis De vil hente den her inden hun rejser, hvilket om Gud vil sker på Søndag.

Med hilsen fra Fru Gr og Asta.

Filippine Larsen.

Indirekte afspejler dette brev en helt ny og venligere indstilling hos fru Gr., hvad der vel hovedsagelig skyldtes beslaglæggelsen af manuskripterne. Sv. Gr. imødekom så hurtigt det var muligt fru Gr.s ønske om en overflyttelse af manuskripterne til Det kgl. Bibliotek. Overflyttelsen fandt sted den I 5 . november, ifølge bevaret kvittering fra overbibliotekar Chr. Bruun, og i biblioteket henstod manuskriptkasserne, der alle stadig var forsynet med Skiftekommissionens segl, i henved to måneder.

Den I5. februar I 873 krævede fru Asta manuskripterne udleveret til sig, thi i mellemtiden var parterne kommet overens om en ordning. Det viste sig bl. a., at fru Asta alligevel helst ville have en mellemmand eller »opmand «, der repræsenterede hende, når der skulle forhandles med Grundtvigerne. Den mand hun valgte, var den meget ansete gehejmeetatsråd, professor dr. med. C. E. Fenger, tillige politiker og borgmester i København. (Han var forøvrigt en yngre broder til N. F. S. Gr.s gamle ven pastor P. A. Fenger.)

Den 20. jan. I873 udsendte nævnte Fenger følgende skrivelse + brev til Brandt og Sv. Gr.:

Deherrer Pastor C. J. Brandt

og Professor S. Grundtvig.

Paa Bispinde Grundtvigs Vegne og ifølge hendes Anmodning har jeg den Fornøielse hoslagt at tilstille Deherrer en af hende til Dem udfærdiget Skrivelse. Samtidig har hun tilskrevet mig med Anmodning 
om at jeg vilde paatage mig de 2 Hverv, som hun i Skrivelsen har udtalt at hun ønskede overtagne af mig, og denne hendes Begjæring er jeg villig til at efterkomme, dersom Sagen derved kan bringes i Orden. -

Kjøbenhavn d. 20. Januar I 873

Deres meget forbundne

Fenger.

Deherrer Pastor C. J. Brandt

og Professor S. Grundtvig.

For at bevirke den heldigste Løsning af de Spørgsmaal, som staae i Forbindelse med Udgivelsen af min afdøde Mand, Biskop N. F. S. Grundtvigs efterladte Skrifter, og for at virke hen til, at denne Udgivelse kan skee saaledes som bedst stemmer med Folkets Tarv og med hans Navn, har jeg besluttet at anmode Deherrer om Deres Bistand med det Arbeide, som i denne Anledning vil være at foretage, idet jeg antager, at Ingen vil kunne udføre dette Arbeide med større Indsigt og Kjærlighed end De. Deres Arbeide vil komme til at bestaae af tvende Hoveddele, at gjennemgaae hans efterladte Haandskrifter, af disse udsøge hvad der egner sig til Offentliggjørelse, og besørge Udgivelsen deraf i den bedste Følgerække og paa hensigtsmæssigste Maade, - og at undersøge, hvilke af hans allerede udgivne Skrifter det vil være rigtigt at udgive paany, og besørge disse udgivne forsaavidt Grundtvig ikke selv har overdraget dette til Andre.

Dette Hverv ønsker jeg at overdrage Dem i Forening, saaledes, at De begge skulle være enige om ethvert Spørgsmaal, som De selv ville afgøre. I Tilfælde af Uenighed imellem Dem vil Spørgsmaalet være at afgøre ved en Opmand, efter hvis Kjendelse da den af Dem, hvem hans Afgjørelse gaaer imod, maa rette sig. Jeg agter at anmode Hr. Geheime-Etatsraad Dr. med. C. E. Fenger om at paatage sig det Hverv at være Opmand i disse Sager, og da jeg tillige ønsker at benytte hans Bistand som Lavværge $\mathrm{i}$ alle hermed forbundne Anliggender, er det mit Ønske, at De i alle Spørgsmaal af oekonomisk Interesse ville henvende Dem til ham.

Da det kan forudsees, at Udgivelsen af Grundtvigs Skrifter kan føre til en ikke ubetydelig Indtægt for mig, som jeg dog ikke ønsker 
at nyde personlig, har jeg besluttet, at hvad der af denne Indtægt bliver tilovers, efter at der er udvirket et passende Honorar til Deherrer for Deres Arbeide, skal deles i to lige store Dele, og at den ene af disse skal tilfalde Grundtvigs fem efterladte Børn til lige Deling; med Hensyn til Anvendelsen af den anden forbeholder jeg mig min nærmere Bestemmelse.

Foruden Haandskrifter, som allerede ere i en saadan Form, at de med liden eller ingen Forandring kunne udgives, har Grundtvig ogsaa efterladt sig andre Optegnelser i Form af Dagbøger, Breve fra ham, Brudstykker af forskjellig Art o. s. v. Med Hensyn til saadanne Optegnelser er det mit Ønske, at de ikke skulle udgives for det Første. Men forsaavidt Nogen af Deherrer maatte ønske selv at forfatte og udgive et biographisk Arbeide over Grundtvig eller skildre ham som dansk Mand og Forfatter, vil der fra min Side ikke blive gjort Indvending imod, at disse Optegnelser med behørig Discretion benyttes ved et saadant Arbeide. Jeg ønsker, at Deherrer ikke uden mit for hvert Tilfælde meddelte Samtykke ville udlaane noget af Papirerne til Andre.

Med Hensyn til de af Papirerne, over hvilke jeg kun disponerer i Forbindelse med de øvrige Arvinger, er det mit Ønske snarest muligt at komme til en Forening ${ }^{20}$ ) med disse om en for alle Parter tilfredsstillende Fordeling; at ethvert Brev eller Dokument, som har Betydning med Hensyn til Udgivelsen af hans Skrifter, maa udleveres mig, anseer jeg som en Selvfølge; ligeledes maa jeg forlange mine egne Breve til ham udleverede; men iøvrigt indskrænke mine Ønsker sig til ganske enkelte Samlinger af Breve til ham.

Jeg udbeder mig nu en Meddelelse fra Deherrer, om De ere villige til at paatage Dem det omhandlede Hverv paa det i denne Skrivelse givne Grundlag.

D. 2ode Januar 1873

Deres meget forbundne

A. Grundtvig.

Denne skrivelse besvaredes af Brandt og Svend Grundtvig med søskende saaledes (kopi ved Jørgen Bloch):

20. »komme til en Forening med disse «. »Forening « må her betyde »enighed «, eller også er »Forening《 en fejlskrivning for: Forhandling. 
Til

Fru Bispinde A. Grundtvig.

I det vi herved, med Paaskjønnelse af den os viste Tillid, erklære os villige til at modtage det os ved Deres Skrivelse af 2ode dennes overdragne Hverv: at forberede og forestaa Udgivelsen af N. F. S. Grundtvigs trykte og utrykte Arbejder, paa den Maade som nærmere er antydet i bemældte Skrivelse, og idet vi tillige med Beredvillighed gaa ind paa og love at rette os efter de i samme givne Forskrifter, skulle vi kun tilføje, at vi levende føle det os derved paalagte Ansvar for Samtid og Eftertid, at vi efter bedste Evne ville stræbe at løse den os stillede Opgave, og at vil ville søge Kraften hertil, næst i Guds naadige Bistand i den Kjærlighed og Ærbødighed for den afdøde Forfatters Personlighed og for hans betydningsfulde Virksomhed, hvoraf vi ere gjennemtrængte. Med Hensyn til den os i samme Skrivelse givne Bemyndigelse til, saa fremt nogen af os maatte tænke paa at udarbejde en Levnedsskildring af Grundtvig, da dertil med fornøden Hensynsfuldhed at turde benytte de mellem hans Efterladenskaber forefundne Optegnelser af mere privat og personlig Art, tro vi allerede nu at burde bemærke, at medundertegnede Svend Grundtvig føler sig kaldet til at forsøge eller i hvert Fald at forberede et saadant Arbejde, som han dog ikke tør tænke paa at udføre før adskillige Aar frem i Tiden.

Da samme Skrivelse fremdeles berører Forholdet med saadanne af N. F. S. Grundtvigs efterladte Papirer, som ikke kunne henføres til dem, der falde ind under Loven om litterær Ejendomsret, men efter de almindelige Regler maatte besiddes i Sameje mellem Dem og Grundtvigs Livsarvinger, saa har medundertegnede Svend Grundtvig, efter dertil given Anledning, herved paa Helsøskendes og egne Vegne at erklære, at Grundtvigs Børn af første Ægteskab, paa Grund af den ved Deres ovennæunte Skrivelse trufne betryggende Ordning med Hensyn til Gjennemgaaelsen af Grundtvigs Papirer, hvilken Sag fremfor nogen anden har ligget dem paa Hjærte, samt i Henhold til de øvrige i samme Skrivelse trufne Bestemmelser, frafalde Kravet paa at faa foretaget nogen Adskillelse imellem hans litterære og private Papirer og alene kunne ønske, at de alle maa forblive samlede og sikrede som de nu ere i Deres Vold og Værge. Hertil tillade vi os endnu at knytte Udtalelsen af det Haab, at Grundtvigs samtlige Arvinger maatte komme overens om at træffe 
en bindende Bestemmelse, hvorved alle hans skrevne Efterladenskaber, saa vel hvad der hidrører fra hans egen Haand som Breve til ham, for saa vidt som de dertil maatte egne sig, senest $5^{0}$ Aar efter hans Død skulle overgives til en offentlig Samling, til fortsat Bevarelse og mulig fornyet Benyttelse i Fremtiden.

Kjøbenhavn og Frederiksberg d. 25de Januar I873.

$$
\begin{aligned}
& \text { Med Højagtelse ærbødigst } \\
& \begin{array}{ll}
\text { C. J. B(randt). } & \text { S. G(rundtvig). }
\end{array}
\end{aligned}
$$

At vi undertegnede, ligesom vi paa Sagens tidligere Standpunkter have været fuldkommen enige med vor Broder Svend Grundtvig, saaledes ogsaa nu tiltræde og bifalde det af ham ovenfor givne Tilsagn angaaende vor Faders private Papirer, bevidnes herved.

$$
\text { d. u. } \mathrm{s}^{21} \text { ) J. G(rundtvig) } \mathbf{M} \text { (eta) B(oisen). }
$$

Ogsaa jeg tiltræder for mit Vedkommende det af mine ældre Søskende givne Afkald paa en Deling af min Faders Papirer.

$$
\text { d. u. s. } \quad F \text { (rederik) G(rundtvig). }
$$

At Ovenstaaende er en tro Afskrift af Conceptet, som helt igjennem er skrevet med Svend Grundtvigs Haand, og findes blandt hans efterladte Papirer, bevidnes.

$$
\text { J. } \left.\text { Bloch }^{22}\right) \text {. }
$$

Resultatet blev altså hvad man kunde kalde en mindelig ordning. Hovedsagen var, at Brandt og Svend Grundtvig fik adgang til at benytte papirerne, medens stridsspørgsmål skulde afgøres af C.E. Fenger. I praksis kom dette til at betyde, at alle forhandlinger i de kommende år kom til at gå gennem Fenger; der synes ikke at have

21. d. u. s. J: datum ut supra 5: tid og sted som ovenfor.

22. arkivassistent Jørgen Bloch var broder til Sv. Gr.s hustru Laura Gr. - Alle i afh. gengivne breve findes i Ny kgl. Saml. $3698,4^{\circ}$. 
fundet nogen personlig kontakt sted mellem fru Asta Gr. og Svend Gr. efter denne affære. Men hvorledes forholdt det sig med sidstnævntes adgang til papirerne, som jo beroede hos fru Gr.? Derom vides foreløbig intet med sikkerhed, men formodentlig har Brandt som gammel husven hos fru Asta påtaget sig dette og på Sv. Gr.s vegne foretaget de nødvendige undersøgelser.

Svend Gr. udgav som bekendt fra 1873 og til sin død i 1883 en række skrifter af Gr., både genoptryk og nyudgivelser. Fremgangsmåden var ved hver udgivelse denne, at Sv. Gr. (i fællesskab med Brandt) skriftligt henvendte sig til Fenger og foreslog en udgivelse. Denne lod brevet gå videre til fru Grundtvig, der med en påtegning gav sit bifald og sendte brevet tilbage til Fenger, som videresendte det (med eventuelle bemærkninger) til Sv. Gr. Derefter kom et møde i stand mellem Fenger, Svend Gr. (eller Brandt) og forlæggeren (i reglen Karl Schønberg), hvor forlagskontrakten undertegnedes. Fenger havde fuldmagt til at underskrive på Asta Gr.s vegne. Det lyder besværligt og har måske også været det $\mathrm{i}$ begyndelsen, men denne fremgangmåde udviklede sig snart til at blive en ren rutinesag. Men alle Sv. Gr.s udgivelser bærer præg af altfor ringe kendskab til Gr.s skriftlige efterladenskaber. Dette blev det »synlige« resultat af den hele historie, og årsagen var den stadig fortsatte kulde mellem de to parter. En lettelse for Sv. Gr. har det været, at han allerede i faderens levetid havde taget en mængde afskrifter af Gr.s papirer og derigennem havde lært hele samlingen grundigt at kende. Alligevel har dette ikke været nok. Der findes aldrig i hans indledninger eller noter nogen udtalelse om de resp. håndskrifters tilstand, nogen opregning, registrering af samtlige mss. til en given tekst, ganske simpelt fordi det ikke har kunnet lade sig gøre, netop på grund af det ovenfor meddelte. Hvad den arbejdsivrige Svend Gr. har følt ved som moden mand ligesom at blive halvvejs stoppet $\mathrm{i}$ sit arbejde på faderens eftermæle, netop som han ved dennes død troede at skulle få fuldstændig adgang til de skriftlige efterladenskaber, vides ikke. Men det må have været ham meget ubehageligt. Selv om der som anført kom en ordning i stand, blev forholdet ikke mere det samme for ham. Og det må beklages for en så ægte videnskabsmand som Sv. Gr. Men skylden er ikke ene Asta Grundtvigs. Et eller andet i Sv. Gr.s personlighed og væsen, den manglende smidighed, den manglende forståelse af en kvinde som hans stedmoder, var medvirkende til, at det gik som det gik. 